${ }_{\text {USGS-OFR-82-478 }}$

USGS-OFR- $82-478$

$\overline{-82-478}$

\author{
UNITED STATES \\ DEPARTMENT OF THE INTERIOR \\ GEOLOGICAL SURVEY
}
Reconnaissance Seismic Refraction Studies at Calico Hills, Wahmonie, and Yucca Mountain
Southwest Nevada Test Site, Nye County, Nevada

\author{
Open-file Report $82-478$ \\ 1982
}

This report is preliminary and has not been reviewed for conformity with

U.S. Geological Survey editorial standards. Any use of trade names is for descriptive purposes only and does not imply endorsement by the USGS.

Prepared by the U.S. Geological Survey

$$
\text { for }
$$

U.S. Department of Energy

Nevada Operations office

(Interagency Agreement DE-AI08-78ET44802) 
published; however, preliminary information from all of these wells was available and used. The Wahmonie site does not yet have a test hole. The sites at Calico Hills (fig. 2) and Wahmonie (fig. 5) are presumed to be underlain by large burled intrusive masses, largely inferred from aeromagnetic anomalies. Extensive hydrothermal alteration, readily apparent in the area surrunding both of these sites (Ekren and Sargent, 1965; McKay and Wi11iams, 1964), obscures the identification of specific 1ithologies with particular velocities. The possible occurrence of mineralization at Calico Hi11s and Wahmonie, based upon interpretations of electrical data (D. B. Hoover, oral commun., 1980), also suggests some complexity with respect to the variation of velocities.

At Yucca Mountain (fig. 8), geologic mapping implies the occurrence of a large block of ash-flow tuffs, which at the surface is not significantly faulted or fractured. On the basis of surface mapping and dri11-hole data, Yucca Mountain appears to be less structura1ly complex than Calico Hills and Wahmonie. Al1 three sites are geologically complex as shown from geologic mapping and dri11 hole data; the present investigation is aimed at exploring In a preliminary fashion the complexity of the subsurface geology in these areas.

\section{CALICO HILLS}

A spread $5.52 \mathrm{~km}$ long was recorded on the north side of Calico Hills (fig. 2) with a geophone spacing of $120 \mathrm{~m}$. Offset shotpoints to the northeast were restricted to a maximum distance of $1380 \mathrm{~m}$; however, shotpoints to the southwest were offset to a maximum of $12 \mathrm{~km}$. A11 shot holes were sha11ow, less than $3 \mathrm{~m}$ deep, with the exception of three shotpoints in Jackass Flats to the southwest, which were drilled to a maximum depth of $18 \mathrm{~m}$. Charge size 


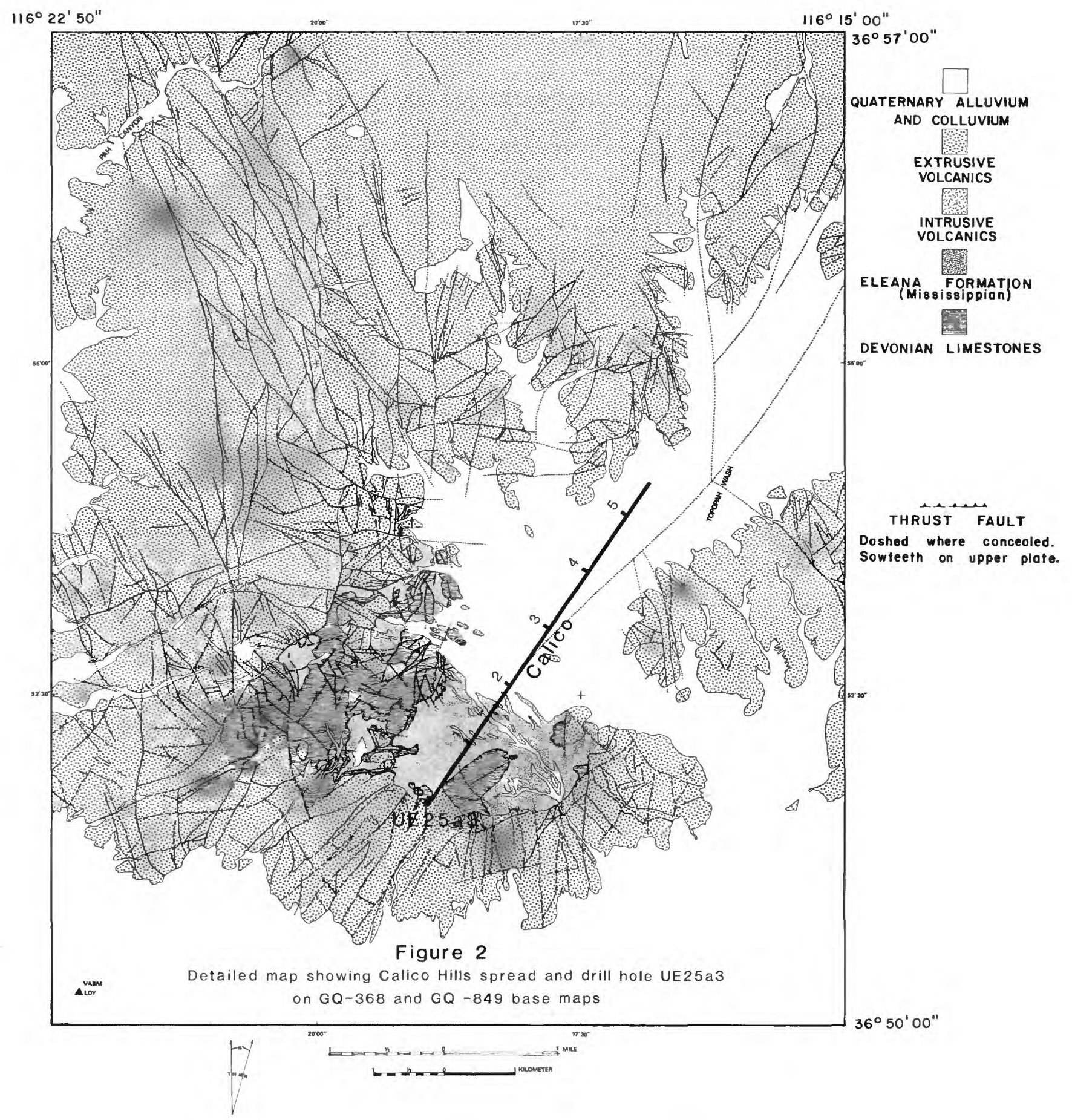


ranged from $9 \mathrm{~kg}$ for the interior spread shots to a maximum of $180 \mathrm{~kg}$ on the farthest offset shots. At several of the offset shot 1ocations, an engineering seismograph was operated using a $30 \mathrm{~m}$ geophone spacing for six geophones in an attempt to record basement arrivals. The time-distance graph was thus effectively extended beyond the recorded spread distance of $5.5 \mathrm{~km}$. The velocity of the deepest horizon recorded by this mini-spread was not significantly different from the bottom layer of the normal spread.

The normal spread begins on Unit $J$ of the Eleana Formation (Mississippian) near the contact with 1imestone and tuffaceous beds. Argillite underlies the spread surficially out to a distance of $2 \mathrm{~km}$ where the alluvium starts and continues through the remainder of the spread. Notable surface outcrops include a rhyolitic intrusion at a distance of $1.4 \mathrm{~km}$, rhyolitic tuffaceous beds at $2.6 \mathrm{~km}$, and tuffs at the extremities of the spread. The seismic spread is nearly parallel to a major inferred fault (Orkild and $0^{\circ}$ Connor, 1970) trending northeast up Topopah Wash.

A 1ithologic description of UE 25a-3 (Ma1donado and others, 1979) indicates that the upper 422.5 meters consists of a high1y fractured argilite, Unit $J$ of the Eleana Formation. Underlying is a unit consisting of therma11y altered argillite to a depth of $720.6 \mathrm{~m}$. This unt contains considerable magnetite, which may account for the large magnetic anomaly observed nearby. The bottom $50.6 \mathrm{~m}$ of the we11 contains an intensely fractured marble, Unit I. At the bottom depth of $771.2 \mathrm{~m}$, no intrusive rock was encountered.

Analysis of the resulting time-distance graph (fig. 3) suggests a model having seven layers of velocity structure. Layer 1 with an average velocity of $0.8 \mathrm{~km} / \mathrm{s}$, is extremely thin to the south; however, it abruptly thickens at about $2.6 \mathrm{~km}$ distance from the source and remains fairly constint Fig. 3 


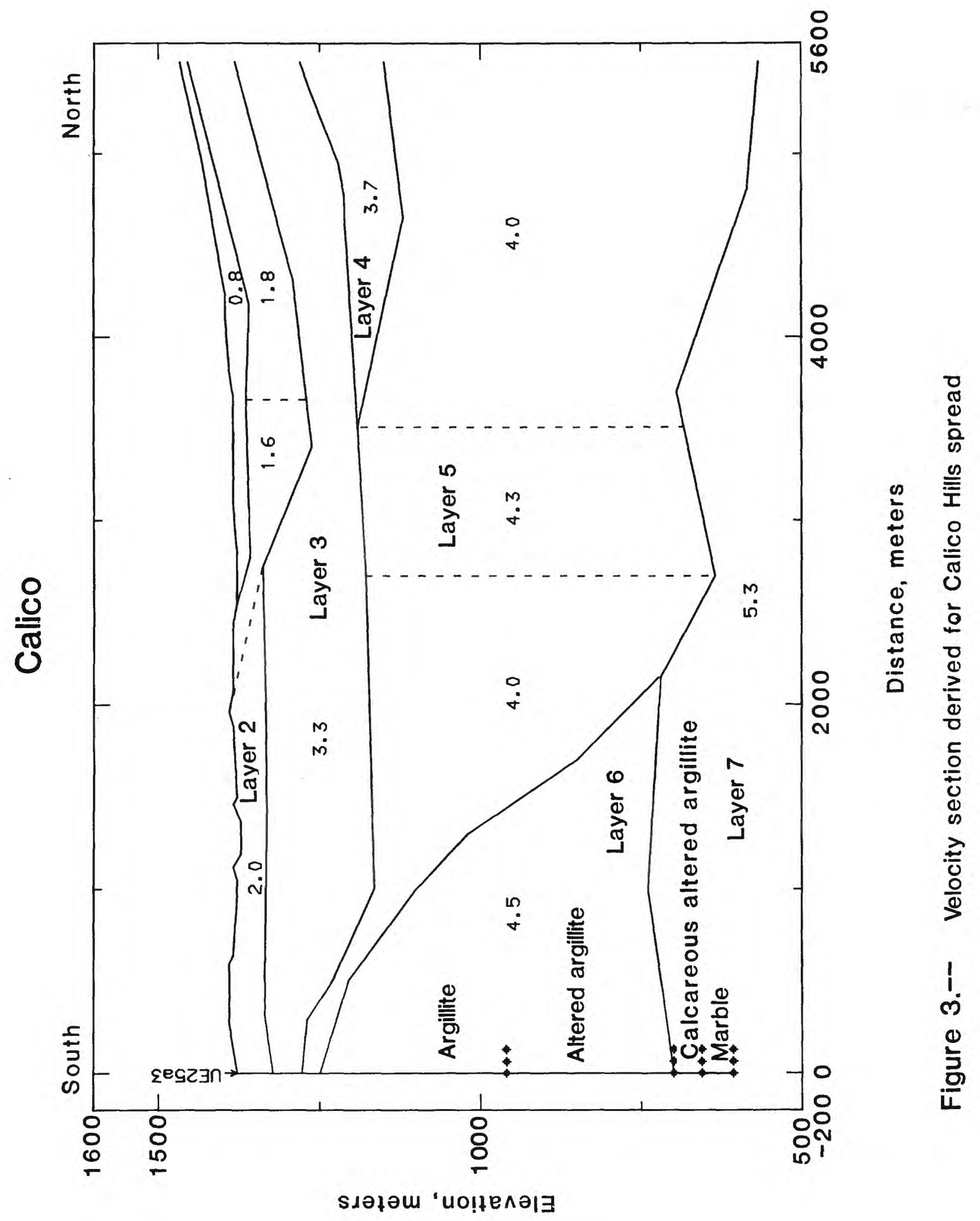


thereafter. This layer is considered to be alluvium. Layer 2 also shows an abrupt thickenng near the $2.6 \mathrm{~km}$ distance as well as a reduction of velocity for the northern two-thirds of the spread. This velocity change may represent a contact zone between the Eleana to the south and rhyolite lava flows to the north. Layer 3 with a velocity of $3.3 \mathrm{~km} / \mathrm{s}$ agrees quite well with the velocity $\log$ of UE $25 a-3$ over the Indicated thickness. Layers 2 and 3 can both be Identifled with Eleana argillite, which has undergone near-surface weathering. Layer 4, represented by a subtle increase in velocity, may indicate a decrease in weathering of the argilite. Layers 5 and 6 may represent units of argillite separated by a sloping interface, similar to an electrical boundary inferred by D. B. Hoover, (oral commun., 1980). This acoustic interface may represent a zonal effect of hydrothermal alteration within the argi11ite. The velocity $\log$ (Ma1donado and others, 1979) for these layers is at least $1.0 \mathrm{~km} / \mathrm{s}$ lower than that indicated by the refracted arrivals. This discrepancy is suggestive of a gross acoustic anisotropy, although part of the difference may be attributable to refracted energy emerging from extremely thin beds. The borehole velocity 10 , model velocity and 11thology are shown in Figure 4.

In summary, the seismic data suggest that, at $2.0 \mathrm{~km}$ the spread crossed a northeast-trending lateral change in velocity at an oblique angle, coinciding with a possible junction between Eleana argillite (Unit J) and rhyolite flows. The change in the thickness of the upper four layers between distances 2.0 to $3.5 \mathrm{~km}$ may be associated with an erosional or structural feature. This change is coincident with the increase in velocity of layer 5, possibly representing alteration within a fracture zone. The bottom layer indicated within the spread has an average velocity of $5.3 \mathrm{~km} / \mathrm{s}$, which agrees closely to the borehole interval and three-dimensional velocity logs. The indicated 


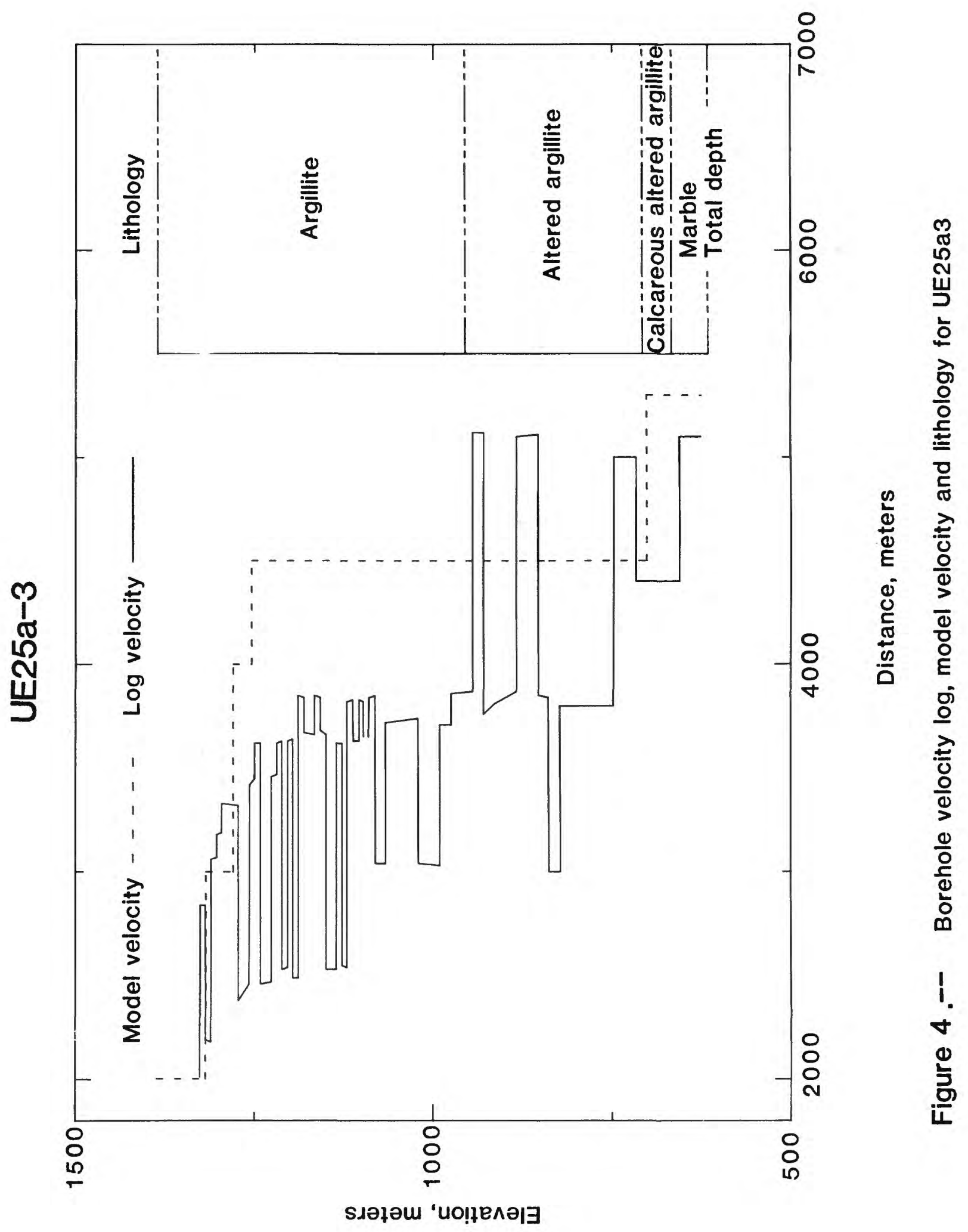


depth of this layer suggests that it is calcareous altered argilitte.

Refracted arrivals from a deeper layer were received on several minispreads and the main spread from long-offset shots; however, the velocity of $5.5 \mathrm{~km} / \mathrm{s}$ is not significantly different from the $5.3 \mathrm{~km} / \mathrm{s}$ interface at $700 \mathrm{~m}$ elevation even though the interpreted depth is greater. This would suggest that if an intrusive is present, no firm interpretation of this deep layer can be given; if it represents an intrusive body, its velocity is not appreciably different from the calcareous altered argi11ite or associated marble.

\section{WAHMONIE}

The geology of the Wahmonie site includes a large $(4.5 \mathrm{~km}$ 1ong by $1.6 \mathrm{~km}$ wide) northeast-trending horst consisting primarily of rhyodacite. Several intrusive bodies occur within the horst, the most notable being granodiorite along the eastern side. The larger body to the northeast encircles the only mapped outcrop of the Eleana Formation in the area. The other intrusive rocks within the horst include andesite, rhyolite, and intrusive breccia. This horst comprises a part of a $50 \mathrm{sq} \mathrm{km}$ zone of hydrothermal a1teration represented by andesites, dacites, latites, and tuffs.

Two spreads were run in the vicinity of the Wahmonie Site (fig. 5) in December 1978 for the purpose of defining an inferred sha11ow intrusive body associated with gravity and magnetic highs. The main intrusive mass was belleved centered north of the Wahmonie South 11ne. Spread Wahmonie East (fig. 6) with 60-m geophone spacing was run eastward from a granodiorite outcrop a distance of $1330 \mathrm{~m}$. Because of inaccessibility due to the terrain, offset shots to the west were not practical. Because the spread started at the edge of the granitic body and possibly due to weathering of the granitic rocks, high velocities near $5.8 \mathrm{~km} / \mathrm{s}$ were not detected near the surface as 


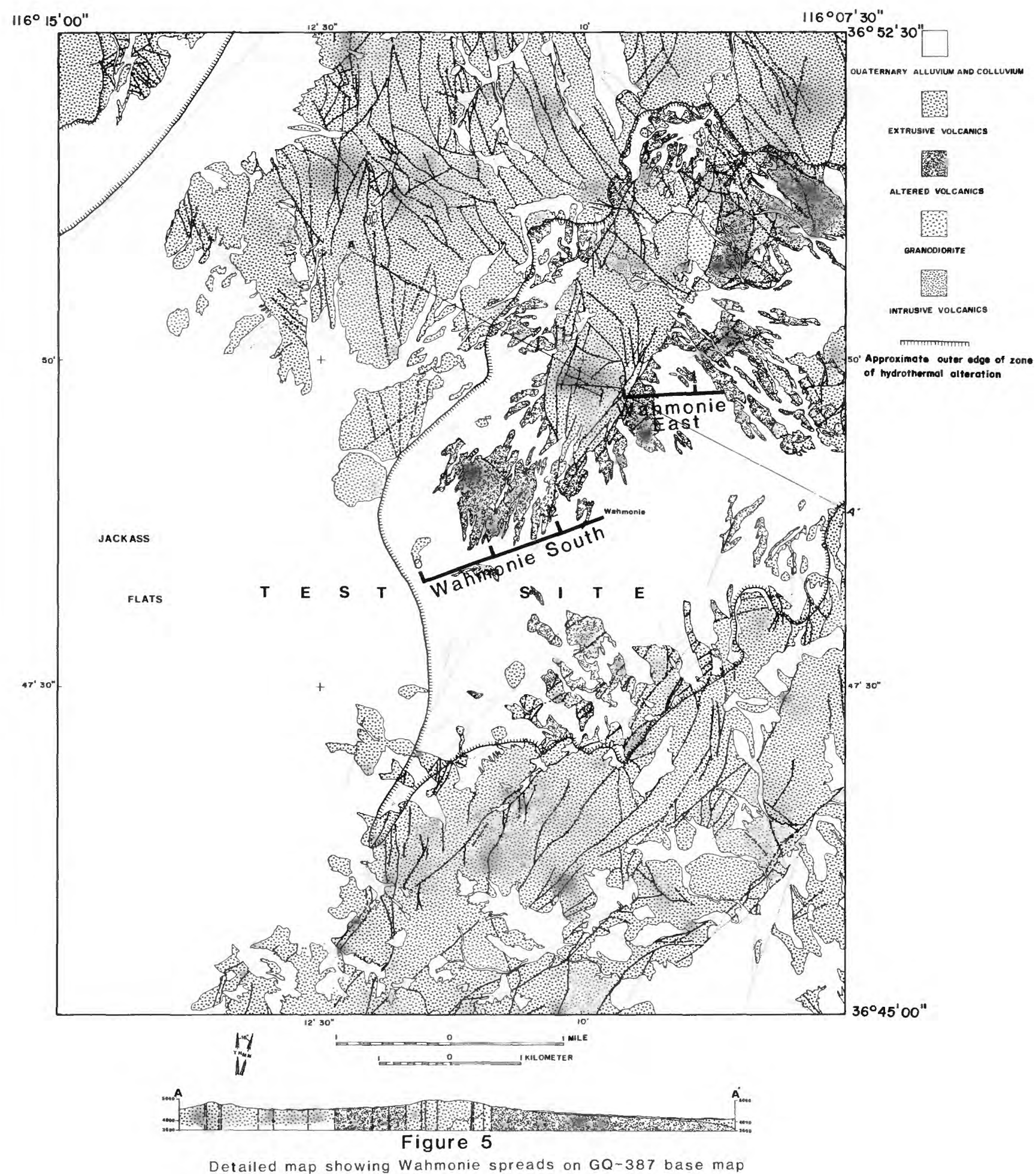




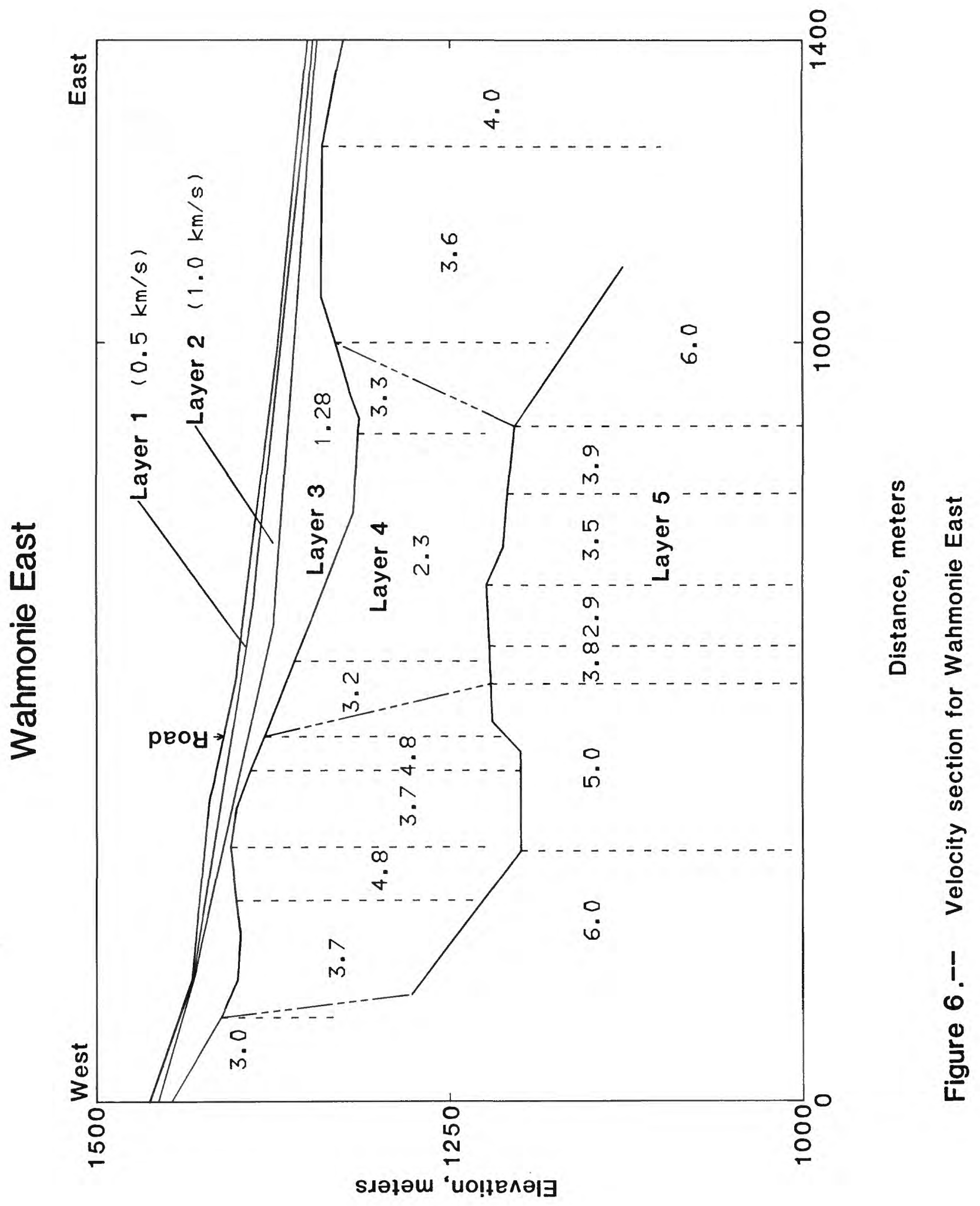


would be expected for unweathered granodiorite. Layers 1 through 3 exhibit normal alluvium velocities ranging from 0.5 to $1.28 \mathrm{~km} / \mathrm{s}$. This alluvial material thickens considerably at two locations near 200 and $800 \mathrm{~m}$. These increases in thickness may manifest the graben structures suggested for layers 4 and 5. Layer 4, where velocities range generally from 2.3 to $4.8 \mathrm{~km} / \mathrm{s}$, has a gently rolling surface with rather sharp velocity contrasts. These velocity contrasts at distances of $580 \mathrm{~m}$ and $875 \mathrm{~m}$ may be due to erosional or structural discontinuities that extend into layer 5. The most striking vertical contrast in velocities of layer 4 occurs at $120 \mathrm{~m}$ distance. The velocity variation of layers 4 and 5 near $140 \mathrm{~m}$ distance may indicate a fault coinciding with a projected fault south of the spread (Ekren and Sargent, 1965). Layer 5 velocities are representative of those for relatively unweathered intrusive rocks $(5.0 \mathrm{~km} / \mathrm{s}$ or greater). A 1ack of refracted arrivals from layer 5 near $140 \mathrm{~m}$, where a fault has been inferred on the basis of geologic studies, may be associated with a low-velocity zone within the depth interval $550 \mathrm{~m}$ to $900 \mathrm{~m}$.

The velocity model for the Wahmonie South spread (fig. 7) was run $2760 \mathrm{~m}$ along a jeep trail known as the Horn Cutoff (fig. 5) terminating at the Wahomonie Site aspha1t road. The first layer has a uniform velocity representing thin allumvium. Layers 2 and 3 seem to relate to the central lower velocity portion of layer 4 of Wahmonie East even though the lowest velocities are somewhat lower along Wahmonie South. Detailed geologic mapping along this spread reveals several faults that correlate positively with the velocity mode1. A fault with a steep westerly dip projected from the south intersects the spread near $1.0 \mathrm{~km}$. The main postulated fault in the area crosses the spread at $1.7 \mathrm{~km}$ and agrees quite well with the boundary between the 1.8 and $1.6 \mathrm{~km} / \mathrm{s}$ velocities in layer 2 . A third projected fault, which 


\section{Copies of this Open-file Report may be purchased from \\ open-File Services Section \\ Branch of Distribution \\ U.S. Geological Survey \\ Box 25425, Federal Center \\ Denver, Colorado 80225}

PREPAYMENT IS REQUIRED

\footnotetext{
Price information will be published in the monthly listing

"New Publications of the Geological Survey"
}

FOR ADDITIONAL INFORMATION

CALL: Commercial: (303)234-5888

FTS: $234-5888$ 


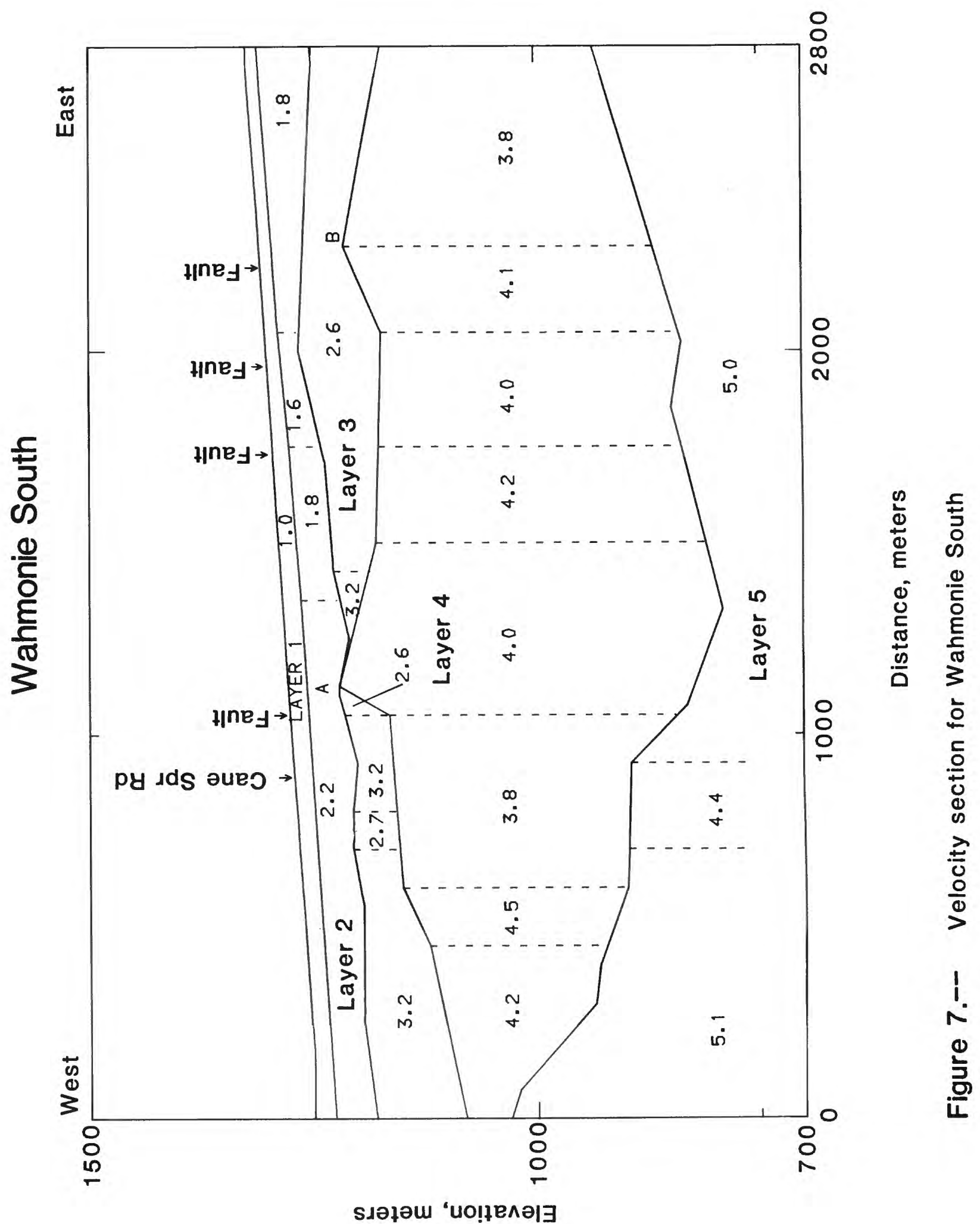


crosses through the Horn Silver Mine, also projects across the spread at point B. In layer 4 two smal1 peaks $A$ and $B$ at 1100 and $2300 \mathrm{~m}$ have been related to corresponding peaks in a gravity profile (David Ponce, oral commun., 1981). In consideration of a magnetic high that occurs near the center of this spread and the gravity anomalies previously cited, layer 4 may represent a buried intrusive body. If so, the low velocities tend to indicate that the material is highly fractured or weathered. As an alternative interpretation, layer 4 may represent a relatively magnetic phase of argillite, similar to that found at Calico Hills. Certainly the velocities are much more representative of this type of rock.

\section{YUCCA MOUNTAIN}

The Yucca Mountain is characterized by multiple bedded tuff formations represented primarily by the Paintbrush Tuff. The members of the Paintbrush Tuff observed near the site of interest include from top to bottom: the Tiva Canyon, Yucca Mountain, Pah Canyon, and Topopah Spring Members. The Yucca Mountain Member is a flat-topped north-south elongated structure with extreme erosional washes trending toward the southeast, presenting a rugged topographic feature. North-south-trending en-echelon faults pervade the area; however, near the northern end of the area the fault structure has changed to an east-west orientation. Near the site, the most prominent exposed rock is tuff of the Tiva Canyon Member. Dips are genera11y less than 10 degrees toward the east.

Three spreads were run in the vicinity of Yucca Mountain (fig. 8) and are indicated on the accompanying map as Yucca 1, Yucca 2b, and Yucca c. A11 of the spreads were $2.76 \mathrm{~km}$ 1ong using $120 \mathrm{~m}$ geophone spacing. Two major problems were experienced. First, much of the area was inaccessible to 


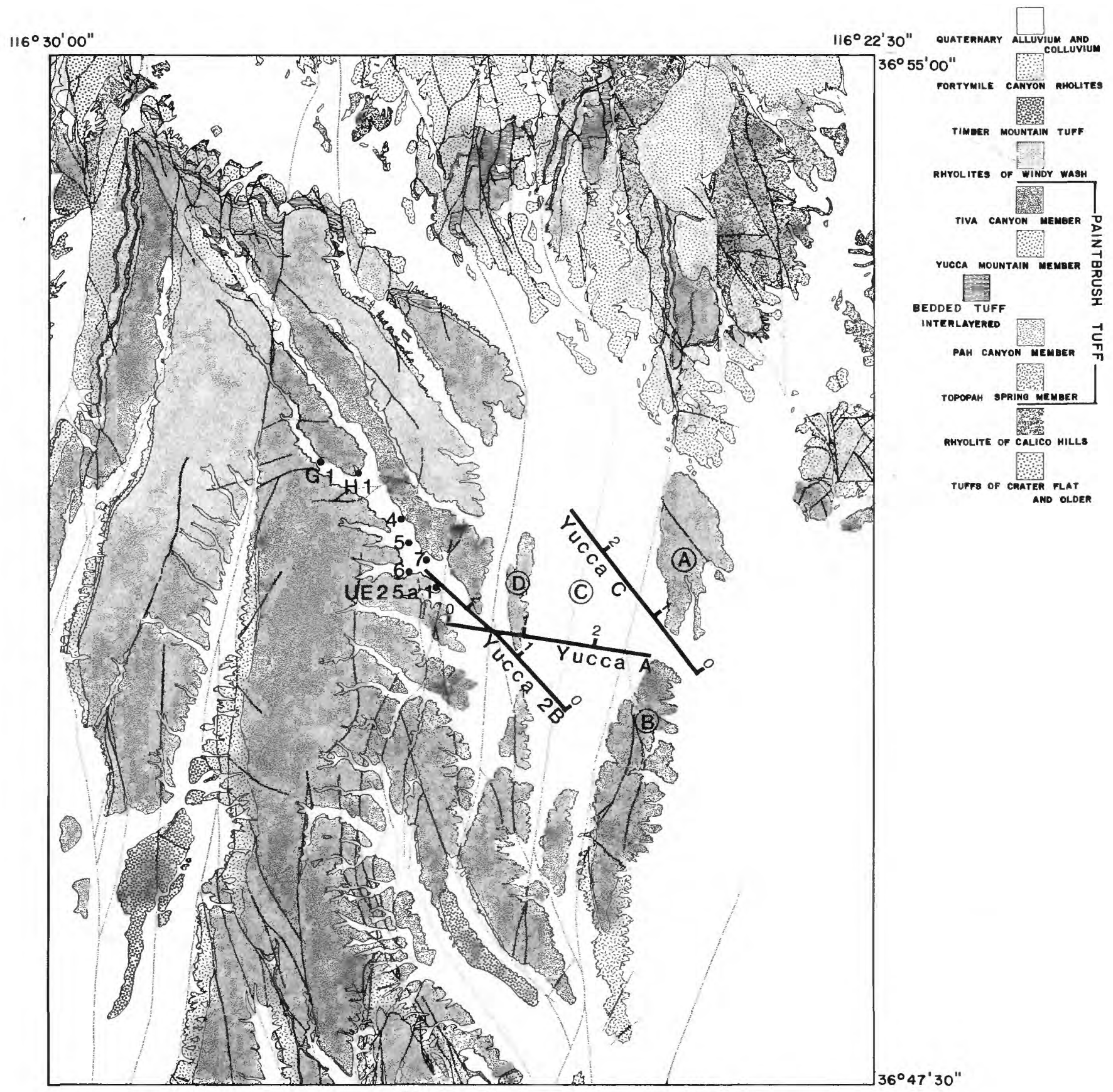

Figure 8

Fo" Detailed map showing the Yucca Mountain spreads and drill hole

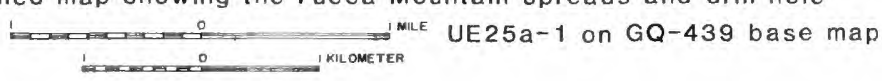


vehicles, which limited the placement of offset shots. Second, a significant increase in the explosive charge size was required due to the difficulty in achleving adequate first breaks from the refracted arrivals. This probably was due to absorption of the seismic energy in the weathered material. When this was coupled with a requirement to place the shots near the surface, it resulted in a data set which was at times incomplete and compromised.

Spread Yucca 1 did not yield readi1y interpretable data because of the poor quality of the refracted arrivals. Spread Yucca 2b (fig. 9), placed primarily in what has been called Drill Hole wash, provided data analysed as a three-layer mode1 to a depth of about $300 \mathrm{~m}$. The velocity structure throughout exhibits considerable horizontal variations, so far having unknown geologic significance. As at Calico Hills, considerable discrepancies exist between velocity and depth information of a we11 $\log$ (UE 25a-1) and equivalent Information derived from the seismic data (fig. 10). The discrepancy here may be attributable to the following factors: (1) poor signa1-to-noise ratio of received energy because of the absorptive characteristic of the subsurface: (2) occurrences of undetected low-velocity layers giving rise to errors in travel time curve analysis; (3) the occurrence of a major vertical discontinuity between materials of contrasting velocity in the vicinity of the spread; or (4) the presence of a strong anisotropy of acoustical impedance. The structure here appears to be complex, suggesting that some faulting is present both parallel and perpendicular to the axis of the valley. The relative mismatch of we11-log and seismic data cautions the user to beware of making excessively detailed interpretations of the derived velocity model. Additional work is vitally needed to pinpoint the cause of the discrepancy to ensure that the seismic technique can be used as a predictive technique for identifying subsurface lithologies and structures in this area. 


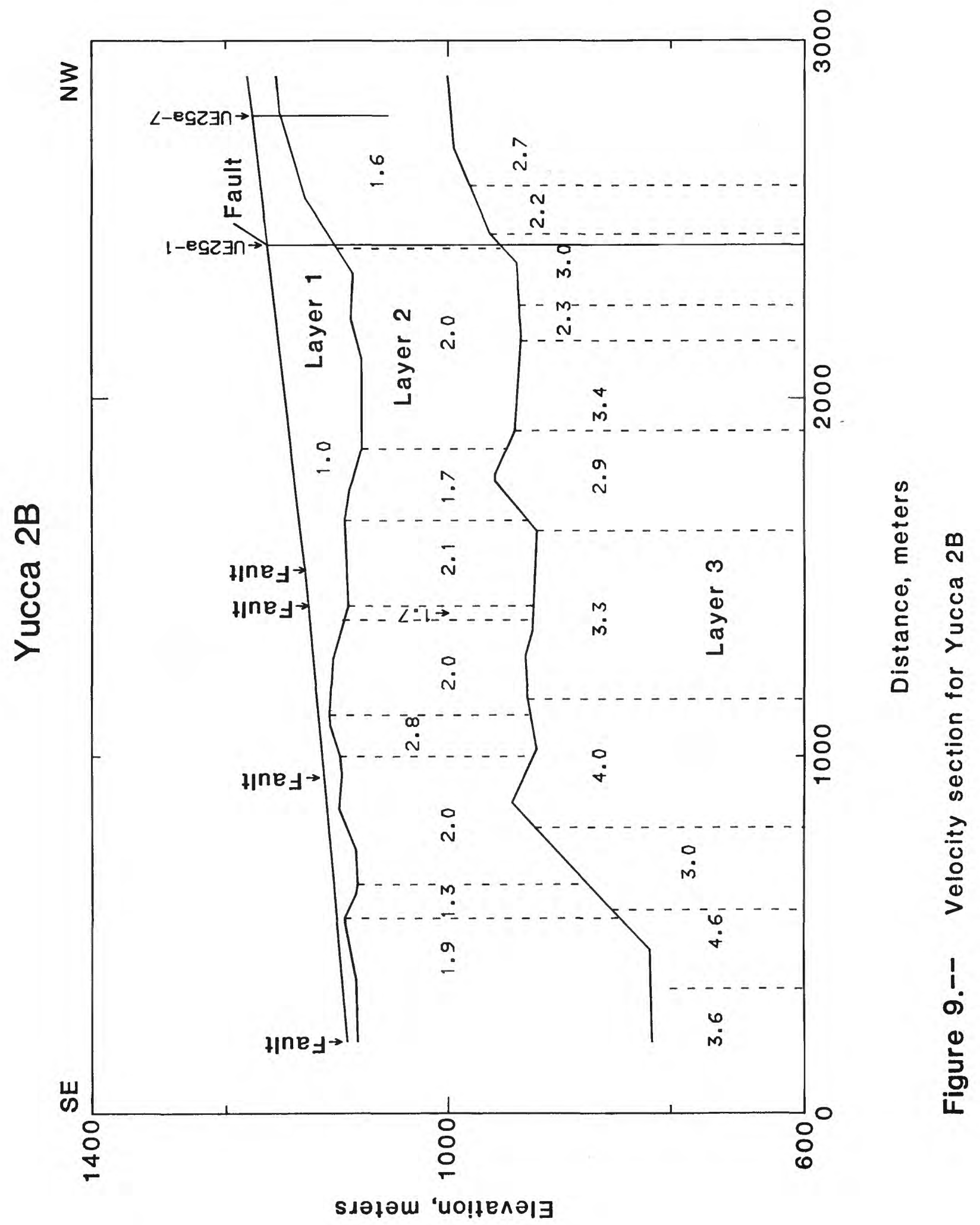




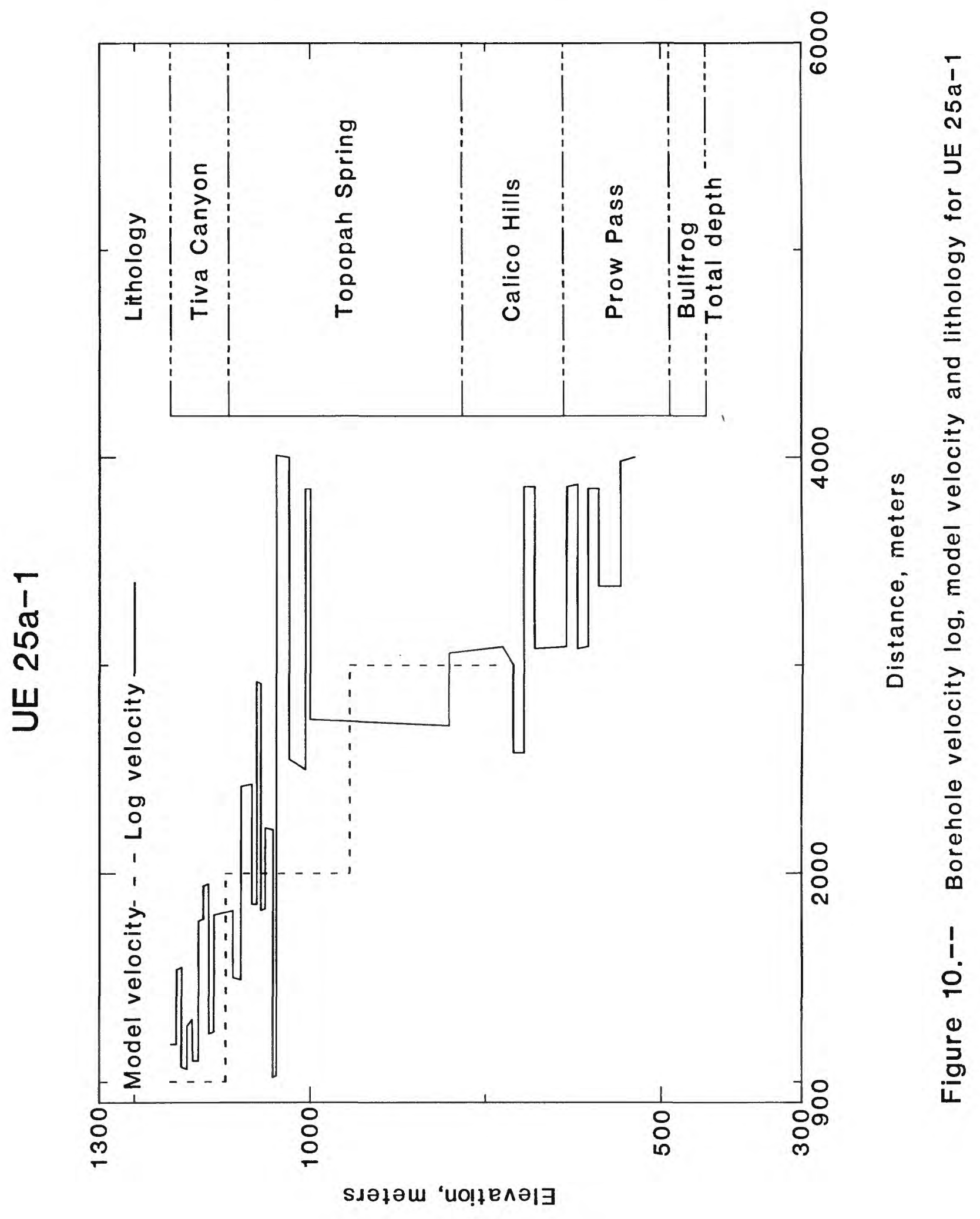


Spread Yucca C (fig. 11) presents near the southeast end of the line a $3.2 \mathrm{~km} / \mathrm{s}$ velocity within $50 \mathrm{~m}$ of the surface at a $500 \mathrm{~m}$ distance. Stratigraphic projections suggest that the interface of the Tiva Canyon and Topopah Spring Members is not deeper than $50 \mathrm{~m}$, consistent with the velocity mode1. However, an abrupt decrease in velocity and steep drop in this horizon is also evident by the velocities not returning to the $3 \mathrm{~km} / \mathrm{s}$ level unt 11 about $880 \mathrm{~m}$. It is apparent that a major fault boundary exists at this location $(540 \mathrm{~m})$ which is nearly in the center of a north-south-trending horst block. One explanation is that a fault trending more westerly than the spread intersects a pass between the two outcrops of the Tiva Canyon Member. The 2.3 $\mathrm{km} / \mathrm{s}$ material may represent major fracturing of the $3 \mathrm{~km} / \mathrm{s}$ rock. This interface is near an electrical boundary that has been used as an electrical callbration fault (D. B. Hoover, personal commun., 1980). The velocities of layer 3 seem to vary as much in this spread as they do along Yucca 2B. Assignment of unit labels to these velocities is difficult, if at all possible. The $1.7 \mathrm{~km} / \mathrm{s}$ unit may be the Tiva Canyon Member with the $2.0 \mathrm{~km} / \mathrm{s}$ material being either lower Tiva Canyon or upper Topopah Spring Member. The horizontal velocity variations should be expected given the significant amount of fracturing or faulting which occurs in the Yucca Mountain area.

\section{CONCLUSION}

Because of the difficulty of matching velocities and depths of the we11 $\log$ data with those inferred from refraction seismic data at Callco Hills and Yucca Mountain additional work is needed to properly assess the discrepancy. It should be noted that the data acquisition and processing techniques and equipment used in this study have proved spectacularly successful in the desert terranes of Arizona and volcanic rock areas of the Snake River 


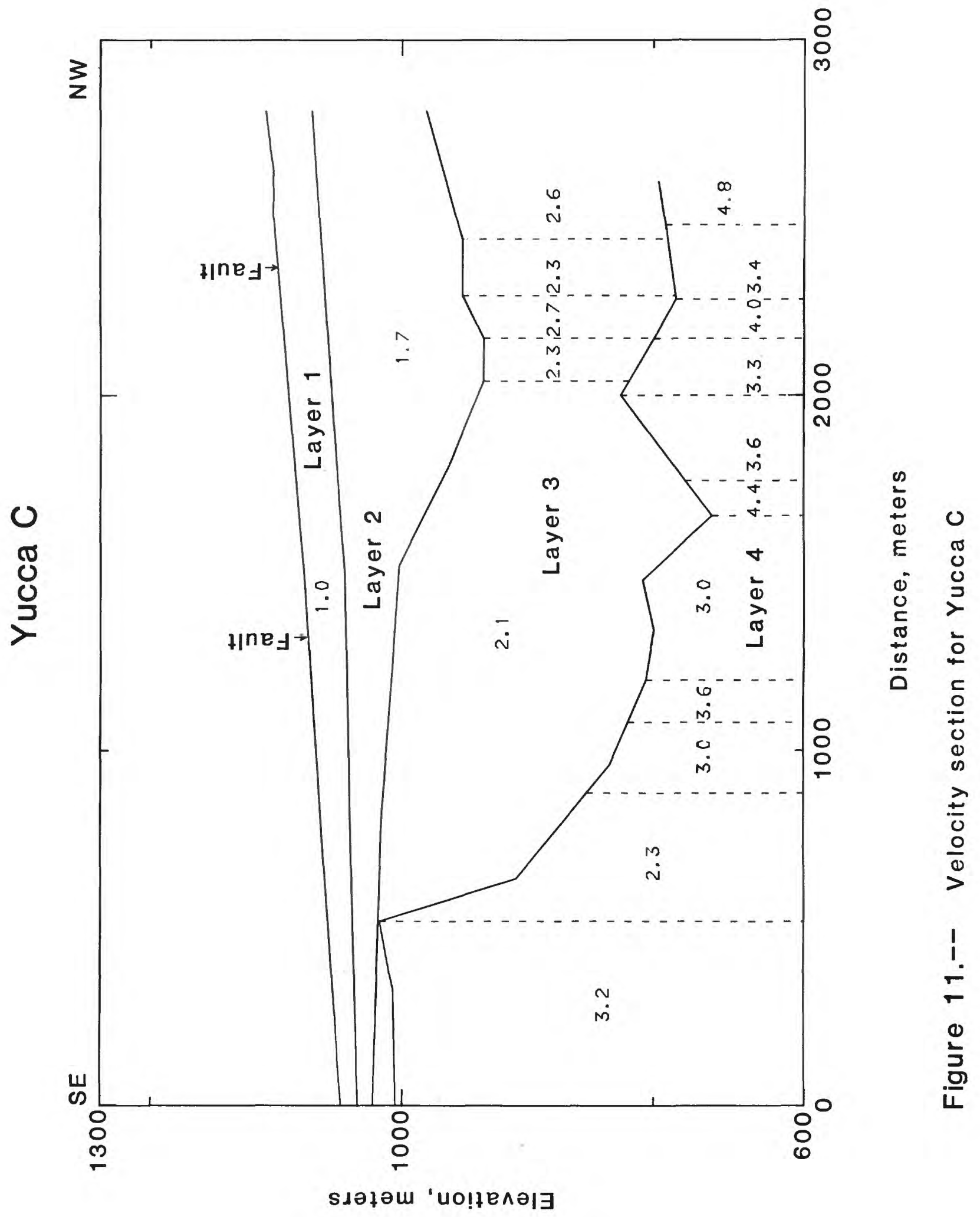


plain. Provided that this discrepancy can be resolved, refraction seismic data should provide more detailed subsurafce information than other geophysical techniques in areas of potential repositories.

\section{ACKNOWLEDGMENTS}

One can never completely express gratitude to those that sacrificed theil extra time and effort to gather data. Thanks are extended to a great crew. Much appreciation is due Hans Ackermann and Don Hoover for their many choice comments during and after the data analysis. 


\section{REFERENCES}

Ackermann, H. D., 1979, Improved resolution from seismic refraction data using interactive computer methods, SEG annual meeting abstracts: Geophysics, 44, p. 388 .

Ekren, E. B., and Sargent, K. A., 1965, Geologic map of the Skull Mountain quadrangle, Nye County, Nevada: U.S. Geological Survey Map GQ-387, scale $1: 24,000$.

Lipman, P., McKay, E., 1965, Geologic map of the Topopah Spring SW quadrangle, Nye County, Nevada: U.S. Geological Survey Map GS-439, scale 1:24,000. Maldonado, F., Muller, D. C., and Morrison, J. N., 1979, Preliminary geologic and geophysical data of the UE 25a-3 exploratory dri11 hole, Nevada Test Site, Nevada: U.S. Geological Survey Report USGS 1543-6, 47 p.; available only from U.S. Department of Commerce, Nationa1 Technical Information Service, Springfie1d, VA 22161.

McKay, Edward, J., and Williams, W. P., 1964, Geology of the Jackass Flats quadrangle, Nye County, Nevada: U.S. Geologica1 Survey Map GS-368, scale $1: 24,000$.

Orki1d, Paul. P., and $0^{\prime}$ Connor, J. T., 1970, Geologic map of the Topopah Spring quadrangle, Nye County, Nevada: U.S. Geological Survey Map GQ-849, scale $1: 24,000$.

Spengler, R. W., Muller, D. C., and Livermore, R. B., 1979, Preliminary report on the geology and geophysics of dri11 hole UE25al, Yucca Mountain, Nevada Test Site: U.S. Geological Survey Open-File Report 79-1244, 43 p. 
GEOLOGICAL SURVEY

Reconnalssance Selsmic Refraction Studies at Calico Hills, Wahmonie, and Yucca Mountain

Southwest Nevada Test Site, Nye County, Nevada

by

L. W. Pankratz

Open-f1le Report $82-478$

1982 





\section{Contents}

Page

I1lustrations list 2

Abstract - 3

Introduction - 4

Ca1ico Hil1s - 6

Wahmonie - 12

Yucca Mountain - 17

Conclusion - 22

Acknowledgments - 24

References - 25 


\section{Illustrations}

Page

Figure 1. Index map of the Nevada Test Site and vicinity showing the areas of investigation

2. Detalled map showing Calico Hills spread and drill hole UE2 $5 \mathrm{a} 3$ on GQ-368 and GQ-849 base maps 7

3. Velocity section derived for Calico Hills spread -

4. Borehole velocity 1 og, model velocity and lithology for UE25a3 - 11

5. Detalled map showing Wahmonie spreads on GQ-387 base map -- 13

6. Velocity section for Wahmonie East - 14

7. Velocity section for Wahmonie South 16

8. Detailed map showing the Yucca Mountain spreads and drill hole UE $25 a-1$ on GQ-439 base map - 18

9. Velocity section for Yucca 2B-20

10. Borehole velocity $\log$, model velocity and lithology for UE25a1 - 21

11. Velocity section for Yucca C 23 


\begin{abstract}
Reconnaissance refraction surveys consisting off a total of 5 spreads were conducted in the Calico Hills, Wahmonie and Yucca Mountain areas, southwestern Nevada Test Site (NTS). Data from Calico Hills and Wahmonie are generally high in quality; data from Yucca Mountain are for the most part low in quality. At Calico Hills and Wahmonie, special attention was focused on the possible occurrence of a major intrusive body at depth. At Calico Hills this occurrence is supported by an inferred dome-shaped velocity interface, possibly associated with the roof of an altered phase of argillite. However, if an intrusive body is present, its top must be buried deeper than $3 \mathrm{~km}$ or it must be so pervasively altered that its velocity is similar to that of the calcareous argillite encountered at the bottom of dri11 hole UE 25a-3. At Wahmonie, the seismic data suggest the occurrence of a massive lenticular unit within $60 \mathrm{~m}$ of the ground surface, probably consisting of argilite but possibly consisting of intensively altered intrusive rock.

At Yucca Mountain, preliminary interpretations of the most reliable data suggest the occurrence of a major, steeply inclined velocity interface $500 \mathrm{~m}$ from the southwest end of the Yucca $C$ spread. This interface may represent a major fault or erosional feature separating the Topopah Spring and Tiva Canyon Members with Paintbrush Tuff at depth. This interface is $800 \mathrm{~m}$ east of a previously mapped fault. On the basis of poor-quality data obtained at Yucca Mountain, the subsurface velocity distribution appears to be complex. For example, one spread near dri11 hole UE25 a-1 suggests not only a much thicker section of Tiva but also that this material is down thrown in the valley. This may suggest faulting with throws exceeding 100 meters or an equivalent erosional feature.
\end{abstract}




\section{INTRODUCTION}

In December 1978 and September 1979, refraction seismic experiments were conducted in the southwest quadrant of the Nevada Test Site to evaluate three areas as possible nuclear waste repository sites. The three areas studied were Calico Hi1ls (Eleana Formation), Wahmonie (intrusive granite) and Yucca Mountain (tuffs).

Data were acquired with an SIE PT-700 analog seismic system using $4.5 \mathrm{~Hz}$ Geospace HS-1 geophones spaced at either $60 \mathrm{~m}$ or $120 \mathrm{~m}$. Each 24-channe1 spread was shot internally and offset from both ends in order to gather reversed data. High velocity explosive charges were used, which varied in size from $4.5 \mathrm{~kg}$ to as much as $180 \mathrm{~kg}$ for some of the long-distant offsets. Maximum amplifier gain was utilized to enhance first breaks. Shot timing was accomplished using a radio-controlled system, and record timing was accurate to .001 second.

Data were analyzed using an interactive ray-tracing computer program (Ackermann, 1979). The model derived from the computer program gives layer depths and lateral velocity variations from which structure can be inferred. Wherever lateral velocities change along the surface of a layer, they are modeled by vertical boundaries called compartments. These compartments, although not necessarily an accurate representation of the geology, do approximate the structure in a simple mathematical way.

The three sites considered in this report are broadly outlined in figure 1 and labeled Calico Hills, Wahmonie and Yucca Mountain. An exploratory dri11 hole UE25 a-3 was drilled to a total depth of $771 \mathrm{~m}$ at Calico Hills with 1ithologic and logging results given by Maldonado and others, (1979). Although nine exploratory drill holes have been drilled in the Yucca Mountain area, only the results from UE25 a-1 (Speng1er and others, 1979) have been 


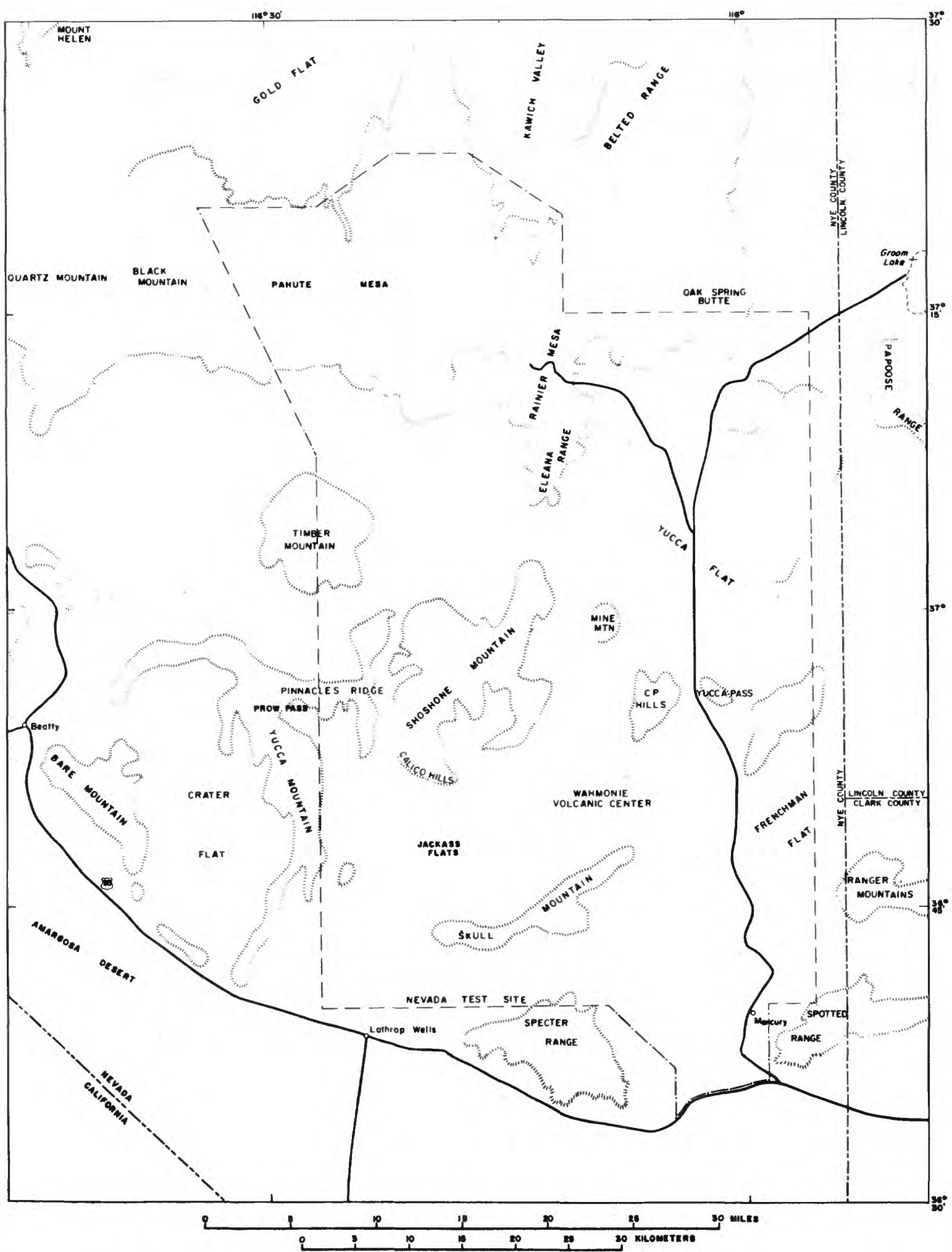

Figure 1-- Index map of the Nevada Test Site and vicinity showing the areas of investigation 